\title{
READINESS ASSESSMENT ON E-GOVERNMENT IMPLEMENTATION IN THE GOVERNMENT OF MANGGARAI REGENCY, INDONESIA
}

\author{
Randang Dionisia Mariani*, Djani William, Rani Laurensius P. Say \\ Master's Program of Administration Science, Postgraduate Program, \\ University of Nusa Cendana Kupang, East Nusa Tenggara, Indonesia \\ *E-mail: dinarandang@gmail.com
}

\begin{abstract}
The purpose of this study is to: (1) describe the readiness of Manggarai Regency in the implementation of e-Government; (2) analyze the factors that inhibit the implementation of eGovernment in Manggarai Regency; and (3) know the projected implementation of eGovernment in Manggarai Regency. Using a descriptive qualitative method witha postpositivism paradigm, this study focused on: (1) analyzing the readiness of e-Government implementation in Manggarai Regency; and (2) the maturity level of e-Government Implementation in Manggarai Regency. The location of the study was in Manggarai Regency, especially in the Information and Communication Agency (leading sector), Development Planning and Research Agency (e-Planning), and Finance Agency (e-Budgeting). Data came from primary and secondary sources. Data were collected through interviews, documentation, and observation. Informants were determined using the purposive sampling technique. The collected data were analyzed using the technique from Miles and Huberman and then validated using a triangulation technique. Findings suggested that the government of Manggarai Regency still has a low level of readiness in the e-Government implementation. Some factors inhibit the implementation of e-Government in Manggarai Regency, including (a) inadequate resources, (b) inadequate infrastructure that supports e-Government, and (c) non-centralized location of regional offices. Besides that, the maturity level of eGovernment implementation in Manggarai Regency has reached the e-interaction level because the website of the government of Manggarai Regency already has a "Contact" menu that displays the e-mail address and telephone number. This enables a two-way interaction between the government and the community.
\end{abstract}

\section{KEY WORDS}

Implementation analysis, e-Government, public service.

Various demands, developments, and changes in the government's paradigm have encouraged the government of Manggarai Regency to start implementing e-Government in providing transparent, effective, and efficient public services. Therefore, the government of Manggarai Regency decided to cooperate with Batang Regency of Central Java Province because the region had already implemented e-Government. That event is marked by signing a Memorandum of Understanding (MoU) by the Regent of Manggarai, Dr. DenoKamelus, SH.MH and the Regent of Batang, H. Wihaji, S.Ag, M.Pd at the office of BatangRegent on October 12, 2017. Some of the e-Government applications planned to be implemented by the Government of Manggarai Regency are e-Budgeting and e-Planning.

The emergence of e-Government is motivated by the planning, preparation, and implementation of administration, accountability, and supervision of the Regional Revenue and Expenditure Budget (Anggaran Pendapatandan Belanja Daerah - APBD) of Manggarai Regency, which is not transparent and effective. This is supported by the findings of Celina (2013). She examined the Regional Financial Management in Manggarai Regency, East Nusa Tenggara, based on the Regional Regulation of Manggarai Regency Number 12 of 2010 concerning the Principles of Regional Financial Management. She found that regional financial management consisted of several stages such as planning, budgeting, implementation, administration, and accountability of APBD. Fundamentally, the Regional Head has the power and is in charge of regional financial management, but in this case, the 
Regional Head can be assisted by regional financial management officials such as the Regional Secretary as the coordinator; Head of Regional Financial Management Unit (Satuan Kerja Pengelola Keuangan Daerah - SKPKD) as Village Finance Manager (Pelaksana Pengelola Keuangan Desa- PPKD), Head of the Regional Official Organizations (Organisasi Peangkat Daerah - OPD) and the Revenue, Financial Management, and Regional Assets Agency as the official users of the budget/goods. The accountability system of the regional financial implementation is carried out by the Regional Head and the Regional House of Representatives (Dewan Perwakilan Rakyat Daerah - DPRD). The Regional Head has the power and is in charge of the people through DPRD. In implementing regional financial management, the government of Manggarai Regency does not have a good government accounting structure that can support a reliable recording and reporting system. The absence of a reliable accounting system has resulted in weak local government internal control. Secondly, only a few local government personnel have an accounting background, so that they do not care about or understand the problems. Besides that, there is still no standard public financial accounting system that is very important to be used as a control mechanism and a guide for preparing financial statements. Nonetheless, the use of performance-based budgets has implications for local governments to make efficient regional expenditures.

Thus, data suggested that the planning, preparation, implementation, accountability, and supervision of the APBD in Manggarai Regency need investigation regarding the fairness of the report, which consistently received the Qualified Opinion. Besides, many findings also were not followed up. In 2015, 2016, and 2017, 41.13\% of findings fromthe Audit Board of the Republic of Indonesiawere not followed up. Therefore, based on the results of previous research and 2015, 2016, and 2017 Implementation Reports of the government of Manggarai Regency, it can be concluded that Manggarai Regency needs to implement e-Government, especially e-Planning and e-Budgeting.

By looking at several aspects above, the researchers found that Manggarai Regency has prepared several things for the implementation of e-Government even though some are still in the process or have not been prepared at all. Unprepared things will undoubtedly inhibit the future implementation of e-Government. Therefore, more in-depth research and analysis are needed regarding the government's readinessof Manggarai Regency in implementing e-Government so that appropriate solutions can be found to overcome the obstacles in implementing the program.

In this study, the researchers analyzed the readiness of Manggarai Regency in the application of e-Government, namely e-Planning and e-Budgeting. It is expected that the readiness of Manggarai Regency in implementing e-Government can be known.

The objectives of this study are to; (1) describe the readiness of Manggarai Regency in e-Government implementation; (2) analyze the factors that inhibit the implementation of eGovernment in Manggarai Regency; and (3) know the projected implementation of eGovernment in Manggarai Regency. It is expected that (1) academically, it can broaden and enrich scientific views, especially in terms of things that the government of Manggarai Regency can do to improve performance and serve the community effectively and efficiently through the implementation of e-Government; (2) practically, this study can be used as inputs for the Government of Manggarai Regency in setting policies related to the implementation of e-Government; and(3), in terms of the development of science, this study is expected to provide information for the academic community and be used as a reference for further research.

\section{LITERATURE REVIEW}

e-Government and Good Governance. The Organization for Economic Co-operation and Development (OECD) (in Misuraca, 2007) said that good governance has eight main characteristics, namely:

1. Participation; participation by men and women is the key to Good Governance. It can be direct or through legitimate representative institutions. Participation should be 
informative and organized. This requires freedom of association and expression as well as a strong and organized civil society.

2. Consensus oriented; there is more than one actor and various points of view in a community. Good governance requires mediation of different interests in society to reach a consensus, the best interest or decision that can be reached for the whole society. This needs a broad and long-term perspective on what is required for sustainable human development. Good governance can only be achieved by understanding the historical, cultural, and social context in the community or society.

3. Accountability; accountability is one of the main requirements in good governance. Not only government institutions, the private sector, and civil society, organizations must also be accounted for by the public and their stakeholder. In general, an organization or institution is accountable to those affected by their actions or decisions. Accountability is impossible without transparency and law.

4. Transparency; transparency means that decision-making and implementation are carried out based on the prevailing laws and regulations.

5. Responsiveness;good governance requires institutions and processes to serve all stakeholders within a specific appropriate time frame.

6. Effectiveness and efficiency; in addition to being efficient in the use of resources, good governance means that the output of all processes and institutions is right on target or following the needs of the community. The concept of efficiency in good governance also includes natural resources, which pay attention to environmental sustainability and protection.

7. Equity and inclusiveness; the existence of a society depends on ensuring that all its members feel that they have an interest in it and do not feel excluded from the mainstream of that society. This requires all groups, especially the weakest, to have the opportunity to strengthen or maintain their existence.

8. The rule of law; good governance require a legal framework or laws and regulations enforced comprehensively. It also requires complete protection of human rights, especially for minorities.

According to the general principles of OECD, it can be said that good governance is when government authority prioritizes the will of the people and being responsive to them. In open governance system, democratic institutions allow full participation in political affairs, and human rights are protected to guarantee the rights to speech, assemble, and disagree. This shows that the government and its agencies stand with the poor and promote the development of all people. In short, it distinguishes between institutions and governance processes and their content and quality.

Indonesia itself is a democratic country. A democratic government places the people as the holder of the highest power. In the concept of good governance, the people play an essential role in government administration and as one of the governance institutions. Governance institutions include the state, private sector, and society (Sedarmayanti, 1997). Considering the position of the people as an institution in governance, the people are one of the essential elements in the state formation theory. Implementing a democratic government requires the involvement of the people in the decision-making process, either directly or through the legislative board.

Electronic Government (e-Government) Concept. e-Government is a government program intended to develop an electronic-based governance system to facilitate the activities of the community and business. The government expects e-Government to help arrange the management systems and work processes through optimal information and communication technology. e-Government has many interpretations as itcan manifest in various forms and scope. Itdepends on the perspective of the defining parties and the level ofdevelopment at the time.

World Bank (in Indrajit, 2004:2) describes e-Government as the use of information technology, such as Wide Area Networks, Internet, and Mobile Computing in government agencies. These thingscan change the relationship with the community, business actors, and government agencies. The Federal Government of the United States (in Indrajit, 2004:3) also 
adds that e-Government refers to the online delivery of information and services through the internet or other digital media. TheUnited Nations Development Programme (in Indrajit, 2004:2) defineit in a simpler way that e-Government is the use of information and communication technology by the government.

According to the OECD (in Misuraca, 2007), the definition of e-Government is divided into three groups as follows:

1. e-Government is the delivery of online services and other internet-based activities such as electronic consulting;

2. e-Government is associated with the use of information and communication technology in government. Although the focus is on service delivery and processing, the broadest definition covers all aspects of government activity; and

3. e-Government is defined as the capacity to change public administration through the use of information and communication technology or, indeed, is used to describe a new form of government built around the information and communication technology. This aspect is usually related to the use of the internet.

From some of the general definitions above, it can be concluded that e-Government is the use of the latest information and communication technology by the government-to provide intensive services to the public, business actors, and government by using webbased applications through the changes of internal and external processes, to reduce corruption and governance costs, and to increase transparency, convenience, and revenues.

Indrajit (2005:13) mentions that selecting the first project of e-Government is crucial for an agency or a local community that never implementse-Government because if the project fails, it will be difficult to continue the initiatives in the future. For this reason, it is necessary to take several crucial steps related to selecting the right e-Government project that follows the needs and existing capabilities. Usually, those who implement e-Government depart from two different causes:

1. The government has certain problems where e-Government is considered to be able to solve the problems, or

2. The government has the intention to improve the series of current performances.

From one of these causes, the government needs or requires to involve information technology in its daily activities. Concerning that, the implementation of e-Government in Manggarai Regency is to improve performance, particularly in the planning and budgeting through the utilization of information and communication technology, especially the internet, as a tool to achieve better governance.

\section{METHODS OF RESEARCH}

This study used a descriptive qualitative research method with a post-positivism paradigm. The focus of this study is (1) analyzing the readiness to apply e-Government in Manggarai Regency and (2) knowing the maturity level of e-Government implementation in Manggarai Regency. This study took place in Manggarai Regency, precisely at the Information and Communication Agency (leading sector), Development Planning and Research Agency (e-Planning), and Finance Agency (e-Budgeting). Data came from primary and secondary sources. There were key informants and supporting informants determined using the purposive sampling technique. Data were collected through interviews, documentation, and observations and analyzed using the technique from Miles and Huberman. After that, the data were validated using a triangulation technique.

\section{RESULTS AND DISCUSSION}

Readiness in the Implementation of e-Government. The rapid advancement of communication and information technology and the potential of its wide use unfold the opportunities for the access, management, and utilization of large volumes of information quickly and accurately. The Presidential Instruction Number 3 of 2003 concerning National Policy and Strategy for the Development of e-Government mentions the use of information 
and communication technology in the government process (e-Government) will increase efficiency, effectiveness, transparency, and accountability of government administration. To carry out good governance and improve effective and efficient public services, it is necessary to have policies and strategies to develop and implement good e-Government.

To realize that, especially in the application of e-Government in government agencies, the government must be responsible for the things mentioned above to improve an effective and efficient service process to the community. This is expected to increase the effectiveness and quality of services provided to the community. Therefore, the implementation of e-Government, especially for e-Planning and e-Budgeting, is hoped to facilitate the work of each regional office in terms of planning and budgeting and increase accountability and transparency to create a clean government.

Therefore, it is also necessary to take the indicators of e-Government into account as it has been stated by Darcy (in Indrajit, 2002) that in the application of e-Governmentmust consider several elements of success, namely: political environment, leadership, planning, stakeholders, transparency/visibility, budgets, and technology. Darcy emphasizes that those elements of success have been analyzed based on the findings of previous research. From there, the researchers can discover the factors causing the low readiness of the Government of Manggarai Regency in implementing e-Government:

1. The legal framework that regulates the implementation of e-Government has not yet been formed;

2. The commitment of the Government to the implementation of e-Government is still low;

3. The utilization of information and communication technology has not been maximized;

4. The human resources areinadequate;

5. The budget for e-Government is still minimal.

In implementing e-Government, the existence of a legal framework is very important. Legal frameworks and instruments are rules that can be used as a basis in the implementation of e-Government. The laws or regulations used in the implementation of ePlanning and e-Budgeting in Manggarai Regency are: (1) Presidential Instruction Number 3 of 2003 concerning National Policies and Strategies for the Development of e-Government and; (2) Regulation of the Ministry of Home Affairs Number 86 of 2017 concerning Procedures for Planning, Controlling, and Evaluation of Regional RegulationDraft as well as Regional Long-Term Development Plans and Regional Medium-Term Development Plans, and Procedures for Amending Regional Long-Term Development Plans, Regional MediumTerm Development Plans, and Regional Government Work Plans.

The development of e-Government in various regions also at least refers to the Presidential Instruction as a juridical basis and is strengthened by Regional Regulations, which are the juridical basis at the regional level. Based on the results of the study, the Government of Manggarai Regency only issued a Circular Letter regarding the Implementation of e-Planning and e-Budgeting. A Circular Letter is an official document containing notification, explanation, and/or instructions on how to do certain things considered important and urgent (source: Regulation of the Ministry of Home Affairs Number 55 of 2010, Article 1 Point 43). Considering that the contents of a Circular Letter are only in the form of a notification, it means that the content does not constitute a legal norm as in statutory regulation.

In other words, Circular Letter cannot be used as a legal basis to annul ministerial regulations or laws but only to clarify the meaning of the regulations to be notified. Therefore, it can be considered that the agreement on the implementation of e-Planning and eBudgeting within the government of Manggarai Regency is less concrete. With the increasingly complex regulations in the implementation of e-Government, this will certainly strengthen the region, especially Manggarai Regency, to implement this program without experiencing regulatory constraints.

From here, it can be concluded that the readiness of the government of Manggarai Regency in implementing e-Government is still low. This can be seen from: 
1. The implementation of e-Government is still based on the Presidential Instruction in 2003 and the Regulation of Ministry of State Apparatus Utilization Number86 of 2017. The Government of Manggarai Regency has just issued a Circular Letter regarding the implementation of e-Planning and e-Budgeting. Meanwhile, there is no Regent's Decree or Regional Regulation yet. The implementation of e-Government is based on the advice of the Corruption Eradication Commission. In this case, no party has rejected the implementation of e-Planning and e-Budgeting. However, socialization has only been carried out for the regional, district, village, and DPRD officials. Other stakeholders, such as the public and the private sector, have not received any socialization;

2. The vision and mission of the Government of Manggarai Regency have not supported the implementation of e-Government. The availability of human resources and supporting facilities such as computers and internet connections are also inadequate;

3. There is no complete planning model for e-Government development; the Government of Manggarai Regency still relies on plans and collaboration with Batang Regency;

4. The limited knowledge of the community in using technology has hindered the function of e-Government from providing information to the public;

5. The data regarding e-Planning and e-Budgeting cannot be accessed by the public yet, so that the function of e-Planning and e-Budgeting as a form of transparency has not been realized;

6. The available budget is not sufficient to meet the needs of e-Government implementation. The government needs to place e-Government as a priority program so that the budget is maximized;

7. Limited budget disturbs the implementation of e-Government technology. For example, it has been not easy to provide integrated access to technologybecause regional offices are not centralized in one area.

Factors that Become Obstacles Related to the Implementation of e-Government in Manggarai Regency. Based on the research results, it can be said that in the future, a Regent Regulation regarding the implementation of e-Government is possible to be formed because the government of Manggarai Regency will continue to move forward and develop e-Government in a better direction. Besides a legal framework, socialization is also part of the political environment that needs to be performed. In this matter, socialization means campaigns to build e-Government to all community members, government, and private sectors to create an efficient government.

The socialization concerning technical guidance on e-Planning and e-Budgeting has been delivered to the government of Manggarai Regency and the heads of regional, district, and village offices and DPRD. The socialization was carried out by experts from Batang Regency with experience in implementing e-Planning and e-Budgeting. It has been stated beforehand that the government of Manggarai Regency has signed a MoU with Batang Regency to implement e-Planning and e-Budgeting. This socialization aims to introduce the application of e-Planning and e-Budgeting to all regional officialswhere this application can simplify the planning and budgeting process while at the same time increasing the level of accountability and transparency of the government. With e-Planning and e-Budgeting, the community can directly supervise the planning and budgeting of the government of Manggarai Regency.

However, the government has not conducted socialization to the entire community of Manggarai Regency about the application of e-Planning and e-Budgeting. This socialization is substantial considering that the purpose of e-Planning and e-Budgeting is to increase transparency to the public. Therefore, the public needs to know about the existence of this application and how to access it. This indicates that at this time, the government of Manggarai Regency is not transparent because the general public cannot access the ePlanning and e-Budgeting applications. As a result, this blocks the realization of the transparency principle in the implementation of e-Planning and e-Budgeting. 
The signs of readiness to implement e-Government can be seen from the political will ofleaders of government institutions to promote the implementation of e-Government. Leaders must not only be smart in drafting concepts but also be a great motivator in the eGovernment implementation phase (Indrajit, 2005). In this case, the Regent of Manggarai Regency has shown the political will to implement e-Planning and e-Budgeting by signing an agreement (MoU) with Batang Regency to transfer the e-Planning and e-Budgeting application to Manggarai Regency. This is a commitment from the leaders to realize governance with high accountability and transparency.

Looking at the vision, mission, goals, and programs of the Government of Manggarai Regency, it is found that none of them supports the implementation of e-Government. Government programs are still focused on improving people's welfare and increasing the level of public education. In Manggarai Regency, e-Planning and e-Budgeting were planned in 2017 and implemented for the first time in 2018. Thus, it can be said that many things have not been prepared. In addition, the unavailability of a master plan for e-Government development is also one of the causes of the low readiness of e-Government implementation in Manggarai. Presidential Instruction Number 3 of 2003 requires the right strategy to build and implement e-Government. One of which is to build e-Government systematically through realistic stages and measurable targets. With the help of a Master Plan, all parties will understand e-Government implementation so that the implementation will be more welldirected.

Another thing that is very crucial for the implementation of e-Government in Manggarai Regency is human resources. Nugroho (2007) writes that one important aspect in the implementation process is the empowerment of human resources. This includes (a) skilful operators to operate applications and carry out related procedures; (b) related officials who understand the new system from the perspective of public service/inter-agency coordination; and (c) technical human resources support to carry out routine maintenance and control.

Moreover, the availability of supporting facilities such as computers and communication infrastructure also needs to be considered for the successful implementation of eGovernment. Those two things are important elements that an electronic-based government must possess. An electronic-based government cannot be realized without that because infrastructure availability is the main element to support various activities. Without adequate infrastructure, various activities cannot run properly and optimally. In this study, the researchers find that Manggarai Regency does not have adequate computers and an internet network. The computers are still very lacking, and the internet network is sometimes slow and does not reach remote areas. This, of course, can hinder the various processes of e-Planning and e-Budgeting implementation.

Based on the results of the study, the obstacles in the implementation of e-Government in Manggarai Regency are:

1. The unavailability of adequate resources. The development of e-Planning and eBudgeting applications still depends on Batang Regency. If malfunction or problems happen with the application, the e-Planning and e-Budgeting operators must contact the programmer in Batang Regency to fix them;

2. The inadequate infrastructure that supports e-Government. The telecommunication network (the internet) has not yet reached remote villages in Manggarai Regency. Internet network is one of the important components in e-Government;

3. The uncentralized location of the regional offices. This hinders the installment of fiber optics for theinternet network in Manggarai Regency because it requires a high cost.

Projection of e-Government Implementation in Manggarai Regency. Referring to the results above, the government of Manggarai Regency has prepared training for their human resources as users or operators in e-Planning and e-Budgeting applications. But, there isstill no technical personnel to solve problems with the application. Thegovernment of Manggarai Regency is still very dependent on Batang Regency if there are problems with the e-Planning and e-Budgeting applications. The availability of human resources or employees who have the competencies and expertise in the implementation of e-Government greatly affects the success of e-Government implementation in Manggarai Regency so that it can follow the 
expected benefits. Without the support of adequate human resources, the electronic-based government will not be implemented optimally.

Managing an e-Government requires human resources with an information technology educational background as they have the technical skills in mastering information technology. Therefore, their level of competence and expertise will greatly affect the performance of e-Government implementation in Manggarai Regency. This means that the higher the level of information technology literacy of the human resources, the better the readiness of Manggarai Regency to implement e-Government. The human resources needed by Manggarai Regency are technicians or operators who can operate the applications well, leaders who understand the new system from the perspective of public services and can coordinate agencies, and supporting personnel who are technically capable of carrying out routine maintenance and control.

The maturity level of the implementation of e-Government in Manggarai Regency has reached the e-interaction level because the Government of Manggarai Regency website already has a "Contact" menu that displays e-mail address and telephone number, enabling a two-way interaction between the government and the community. Based on the results of the SWOT analysis, the researchers found four strategies that the Government of Manggarai Regency must carry out to develop e-Government, namely;

1. Strengthening e-Government development policies by creating a legal framework to govern the implementation of e-Government in the government of Manggarai Regency;

2. Optimally utilize information technology for e-Government services, both government and public;

3. Develop the human resources capacity;

4. Coordinate budgeting for the complete development of e-Government in the government of Manggarai Regency.

\section{CONCLUSION}

Based on the results and discussion above, it can be concluded that;

1. The level of readiness of the Government of Manggarai Regency in e-Government implementation is still low;

2. There are several inhibiting factors in implementing e-Government in Manggarai Regency,including inadequate human resources, inadequate infrastructure that supports e-Government, and uncentralized regional office location;

3. The maturity level of e-Government implementation in Manggarai Regency has reached the e-interaction level marked by the availability of the "Contact" menu on the government of Manggarai Regency website. It enables a two-way interaction between the government and the community because it contains an e-mail address and telephone number.

\section{SUGGESTIONS}

Findings confirm that thegovernment of Manggarai Regency need to pay attention to some factors related to the readiness of e-Government implementation.

For the Government of Manggarai Regency, it is suggested to pay more attention to several important aspects for the optimization ofe-Government implementationin Manggarai Regency, such as:

- Master Plan for e-Government Development that provides a basis for thinking, standardization, phasing, and implementation for comprehensive, efficient, effective, and integrated e-Government development;

- The use of the latest data and information on the government of Manggarai Regency website;

- The government of Manggarai Regency also needs to pay attention to the availability of infrastructure in the region as the main support to serve the community; 
- The government of Manggarai Regency has to recruit more human resources or do training for application development, especially in terms of e-Planning and eBudgeting applications;

- More intensive and sustainable socialization to the public regarding the implementation of e-Planning and e-Budgeting is needed. This can be realized by socialization using various existing media, such as posters, billboards, banners, and the internet. Likewise, it also can be done through direct socialization to the community, such as seminars and counseling, so that the socialization can be more effective and on target.

\section{REFERENCES}

1. Celina, Priska. 2013. "Pengelolaan Dan Sistem Pertanggungjawaban Pelaksanaan Keuangan Daerah Di Kabupaten Manggarai Nusa Tenggara Timur Berdasarkan Peraturan Daerah Kabupaten Manggarai Nomor 12 Tahun 2010 Tentang Pokok-Pokok Pengelolaan Keuangan Daerah". Artikel IImiah Hasil Penelitian Mahasiswa 2013. UNEJ.

2. Misuraca, G. 2007. "e-Governance in Africa: From Theory to Action: A Handbook ICTs for Local Governance (Ottawa IDRC, 2007).

3. Sedarmayanti. 1997. Tata Kearsipan Dengan Manfaat Teknologi Modern. Bandung: Ilham Jaya.

4. Indrajit, Richardus Eko. 2004. Electronic Government (Strategi Pembangunan dan Pengembangan Sistem Pelayanan Publik Berbasis Teknologi Digital). Yogyakarta: ANDI.

5. Indrajit, Richardus Eko. dkk. 2005. E-government in Action. Yogyakarta: ANDI.

6. Miles,M.B, Huberman,A.M, dan Saldana,J. 2014. Qualitative Data Analysis, A Methods Sourcebook, Edition 3. USA: Sage Publications. Terjemahan Tjetjep Rohindi Rohidi, UIPress.

7. Indrajit, Richardus Eko (2002). Membangun Aplikasi E-Government. Jakarta:PT Elek Media Komputindo.

8. Nugroho, Riant Dwijodijoto. 2003. Kebijakan Publik: Formulasi, Implementasi, Evaluasi, Jakarta: PT. Elex Media Komputindo Kelompok Gramedia. 